\title{
Benefit-Based Tree Valuation
}

\author{
E. Gregory McPherson
}

\begin{abstract}
Benefit-based tree valuation provides alternative estimates of the fair and reasonable value of trees while illustrating the relative contribution of different benefit types. This study compared estimates of tree value obtained using cost- and benefit-based approaches. The cost-based approach used the Council of Landscape and Tree Appraisers trunk formula method, and the benefit-based approach calculated the net present value (NPV, total future benefits minus costs discounted to the present) of future benefits and costs using tree growth data and numerical models. In a hypothetical example, the value of a 40 year old green ash (Fraxinus pennsylvanica) was $\$ 5,807$ using the cost-based approach and either $\$ 3,102$ (for a tree growing in Fort Collins, CO, U.S.) or $\$ 5,022$ (for a tree growing in Boulder, CO) using the benefit-based approach. This example, however, did not consider planting and management costs. In a multitree example, 15 years after planting five pistache (Pistacia chinensis) street trees in Davis, California, the trunk formula (cost-based) value was $\$ 8,756$, whereas the benefit-based value NPV of benefits was negative at discount rates ranging from $0 \%$ to $10 \%$. Negative NPVs occurred because future sidewalk repair costs were projected to be in excess of benefits, a relationship not fully captured in the cost-based approach to valuation. Removing and replacing the five pistache street trees was not cost-effective at $7 \%$ and $10 \%$ discount rates, primarily because high future sidewalk repair costs associated with retaining the trees were heavily discounted. Planting the five pistache trees in their current location was not an economically sound decision, but planting the same trees in a nearby shrub bed would have saved an estimated $\$ 1,102(10 \%)$ to $\$ 12,460(0 \%)$ over 40 years. These examples illustrate the use of the benefit-based approach as a decision support tool for design and management.
\end{abstract}

Key Words. Tree appraisal; tree benefits; tree value; trunk formula method.

Establishing the value of trees is fundamental to arboriculture and urban forestry. Without an estimate of tree value, there is little to motivate investment in tree management. Without investment in tree management, the health and functionality of trees deteriorates. When trees are viewed more as liabilities than assets, they are removed and too often not replaced. As tree canopy cover diminishes, our communities become less livable.

The value of a tree, defined as its monetary worth, is based on people's perception of the tree (Cullen 2000). Tyrvainen (2001) reviewed different approaches to determine the value of urban forest benefits. Hedonic pricing relies on differences in housing prices to reflect the value of nearby greenspace. Contingent valuation is based on surveys that ask what people are willing to pay for greenspace. Average willingness to pay is multiplied by the total number of consumers to estimate greenspace value. The travel-cost method uses the costs of travel as a proxy for the price that people are willing to pay for recreational benefits of greenspace. Each of these methods has advantages and limitations. However, these approaches do not isolate the benefits of individual trees within forest stands.
Arborists use several methods to develop a fair and reasonable estimate of the value of individual trees (Council of Tree \& Landscape Appraisers 2000, Watson 2002, Cullen 2005). The cost approach is widely used today and assumes that value equals the cost of production (Cullen 2002). The market approach determines tree value based on the exchange of real property, often using historical sales prices of comparable assets. The income approach measures value as the future use of a tree such as in fruit or nut production. In the absence of products, the income approach could be based on the present value of future benefits the tree is likely to produce (Council of Tree \& Landscape Appraisers 2000). It is this last approach, henceforth called the benefit-based approach, that is the subject of this article.

Until recently, it was difficult to estimate the future stream of benefits that a tree might provide. The growth rates of urban trees were not well documented, their benefits were known in only general terms, and reasonable ways of determining the value of their services were largely theoretical. Recent advances in each of these three areas make it possible to develop reasonable estimates of the benefits trees do and will produce (McPherson et al. 2005b). This article presents 
two examples that demonstrate application of benefit-based tree valuation. The first estimates the value of a tree based on its replacement cost and based on the benefits it produces over 40 years. The second example estimates the current value of five street trees using cost- and benefit-based approaches. Ways that costs and benefits can be used to evaluate management decisions regarding tree removal and replanting are illustrated using the five-tree example.

\section{METHODS-SINGLE-TREE EXAMPLE}

\section{Cost Approach}

The trunk formula method (Council of Tree \& Landscape Appraisers 2000), also called depreciated replacement cost, may be the most commonly used approach for estimating tree value. It assumes that the benefits inherent in a tree can be reproduced by replacing the tree and therefore, replacement cost is an indication of value (Cullen 2000). Replacement cost is depreciated to reflect differences in the benefits that would flow from an "idealized" replacement compared with the older and imperfect appraised tree.

The trunk formula method uses tree size, species, condition, and location factors to determine tree value. Tree size is measured, whereas species adaptability, condition, and location are assessed subjectively relative to a "high-quality" specimen and expressed as percentages. The equation is

$$
\begin{aligned}
\text { Appraised Value }= & \text { Basic Tree Cost } \times \text { Species } \% \\
& \times \text { Condition } \% \times \text { Location } \% \\
\text { Basic Tree Cost }= & {\left[\left(\mathrm{TA}_{\mathrm{A}}-\mathrm{TA}_{\mathrm{R}}\right) \times \text { Unit Cost }\right] } \\
& + \text { Installed Cost }
\end{aligned}
$$

where

$$
\begin{aligned}
\text { Species\% } \% & \text { rating of the species' longevity, mainte- } \\
& \text { nance requirements, and adaptability to } \\
\text { the local growing environment (Council } & \text { of Tree \& Landscape Appraisers 2000). } \\
& \text { A higher percentage indicates a more ap- } \\
\text { propriate species choice. } & \\
\text { Condition\% }= & \text { rating of structural integrity and health; a } \\
& \text { higher percentage indicates better condi- } \\
& \text { tion (Council of Tree \& Landscape Ap- } \\
& \text { praisers } 2000) . \\
\text { Location\% }= & \text { rating of the site itself (relative market } \\
& \text { value), contribution of the tree in terms } \\
& \text { of its aesthetic and functional attributes, } \\
& \text { and placement, which reflects the effec- } \\
& \text { tiveness of realizing benefits; location is } \\
& \text { the sum of site, contribution, and place- } \\
& \text { ment divided by three. A higher percent- } \\
& \text { age indicates better location. } \\
\mathrm{TA}_{\mathrm{A}}= & \text { trunk area of appraised tree }\left(\mathrm{cm}^{2}\right) .
\end{aligned}
$$

\author{
$\mathrm{TA}_{\mathrm{R}}=$ trunk area of replacement tree $\left(\mathrm{cm}^{2}\right)$. \\ Unit Cost $=$ cost of the largest available transplant- \\ able tree divided by $\mathrm{TA}_{\mathrm{R}}\left(\$ / \mathrm{cm}^{2}\right)$. \\ Installed Cost $=$ sum of the cost of the replacement tree \\ (of size $\mathrm{TA}_{\mathrm{R}}$ ) and its installation.
}

This example considers a green ash (Fraxinus pennsylvanica) that was planted approximately $6 \mathrm{~m}(19.8 \mathrm{ft})$ opposite the west-facing wall of a typical single-family residence in Fort Collins, Colorado, U.S. The trunk formula was used to estimate annual value as the tree grew for 40 years assuming that the tree's condition and location ratings remained constant. Annual growth was determined from regression equations of trunk diameter at breast height (dbh) on tree age. The best-fit growth equation was developed with data measured from 63 green ash street trees in Fort Collins during 2002 (McPherson et al. 2003).

Based on regional information, the unit cost was $\$ 7.60 / \mathrm{cm}^{2}$ $\left(\$ 49 / \mathrm{in}^{2}\right)$ for a $6.4 \mathrm{~cm}(2.6 \mathrm{in}) \mathrm{dbh}$ tree with a replacement cost of \$240 (Cassel 2004). Installation cost was \$360 and installed cost was $\$ 600$. In the Rocky Mountain Regional Supplement (Cassel 2004), the species rating for green ash cultivars ranged from $50 \%$ to $70 \%$, so a value of $60 \%$ was selected. Condition and location ratings were arbitrarily set at $70 \%$ and $80 \%$, indicative of a tree in good health with a well-thinned crown located in an average neighborhood placed to protect the home from summer afternoon sun and enhance the property's curb appeal.

\section{Benefit Approach}

A number of benefits and their monetized values were calculated for the same green ash tree located opposite the west wall of a typical residence in Fort Collins (see McPherson et al. 2003 for detailed information on the numerical models and assumptions). Growth data presented at 5 year intervals for 40 years after planting were annualized with linear interpolation. Benefits were modeled using tree growth and size data developed for green ash street trees in Fort Collins (Figure 1).

\section{Energy Savings}

Changes in building energy use resulting from tree shade were based on computer simulations that incorporated building, climate, and shading effects (McPherson and Simpson 1999). Typical meteorologic year (TMY) weather data for Denver and local building characteristics were used. The dollar values of electrical energy $(\$ 0.78 / \mathrm{kWh})$ and natural gas $(\$ 0.068 / \mathrm{MJ}[\$ 0.072 / \mathrm{kBtu}])$ were based on retail residential electricity and natural gas prices obtained from local utilities (Table 1).

\section{Atmospheric Carbon Dioxide Reductions}

Sequestration, the net rate of $\mathrm{CO}_{2}$ storage in above- and belowground biomass over the course of one growing season, was calculated with Fort Collins tree growth data and, lacking 


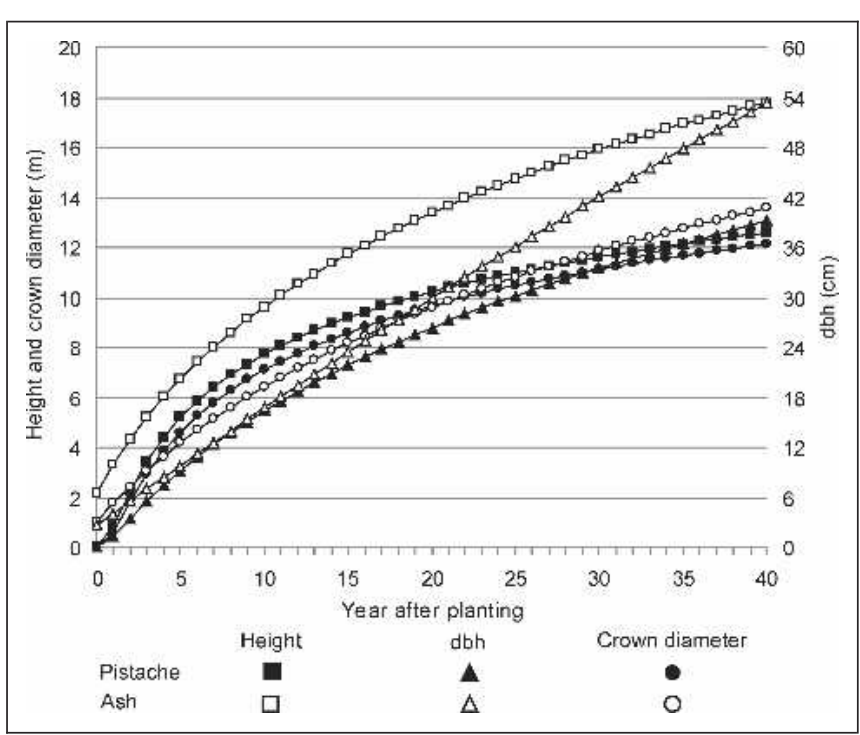

Figure 1. Predicted size of green ash and pistache trees based on street tree data from Fort Collins, Colorado, and Modesto, California.

a biomass equation for an urban green ash, a congener (Fraxinus velutina 'Modesto') (Pillsbury et al. 1998) was used. Carbon dioxide released through decomposition of dead woody biomass was based on an average annual tree removal rate of $0.8 \% . \mathrm{CO}_{2}$ released as a result of tree maintenance activities was estimated based on annual consumption of gasoline and diesel fuel as $0.14 \mathrm{~kg} / \mathrm{cm}$ dbh $(0.78 \mathrm{lb} / \mathrm{inch} \mathrm{dbh})$ (McPherson et al. 2003).

Reductions in building energy use result in reduced emissions of $\mathrm{CO}_{2}$. Emission reductions were calculated as the product of energy savings and $\mathrm{CO}_{2}$ emission factors for electricity and heating. Heating fuel was natural gas, whereas the fuel mix for electrical generation was $78 \%$ coal, $16 \%$ hydro, $5 \%$ natural gas, and $1 \%$ other. The value of $\mathrm{CO}_{2}$ reductions was $\$ 0.017 / \mathrm{kg}\left(\$ 15 /\right.$ ton $\left.\mathrm{CO}_{2}\right)$ based on the average of high and low estimates by CO2e.com (2002).

Table 1. Monetized value of benefits for the single-tree example in Fort Collins and the multiple-tree example in Davis.

\begin{tabular}{lcc}
\hline Benefits & Ft. Collins & Davis \\
\hline Electricity $(\$ / \mathrm{kWh})$ & 0.78 & 0.12 \\
Natural gas $\$ / \mathrm{MJ})$ & 0.068 & 0.061 \\
Runoff avoided $\left(\$ / \mathrm{m}^{3}\right)$ & 2.85 & 0.460 \\
$\mathrm{CO}_{2}(\$ / \mathrm{kg})$ & 0.017 & 0.033 \\
$\mathrm{O}_{3}(\$ / \mathrm{kg})$ & 6.77 & 8.48 \\
$\mathrm{PM}_{10}(\$ / \mathrm{kg})$ & 11.31 & 9.84 \\
$\mathrm{NO}_{2}(\$ / \mathrm{kg})$ & 6.77 & 8.48 \\
Volatile organic hydrocarbons $(\$ / \mathrm{kg})^{2}$ & 10.69 & 3.32 \\
Aesthetics/other $\left(\$ / \mathrm{m}^{2}\right)$ & 232.71 & 553.60 \\
\hline
\end{tabular}

\section{Air Quality Benefits}

The hourly pollutant dry deposition per tree was expressed as the product of deposition velocity $V_{\mathrm{d}}=1 /\left(R_{\mathrm{a}}+R_{\mathrm{b}}+R_{\mathrm{c}}\right)$ (where $R_{\mathrm{a}}, R_{\mathrm{b}}$, and $R_{\mathrm{c}}$ are aerodynamic, boundary layer, and stomatal resistances), pollutant concentration $C$, canopy projection area $C P A$, and a time step. Hourly deposition velocities for ozone $\left(\mathrm{O}_{3}\right)$, nitrogen dioxide $\left(\mathrm{NO}_{2}\right)$, sulfur dioxide $\left(\mathrm{SO}_{2}\right)$, and particulate matter of $<10 \mu \mathrm{m}$ diameter $\left(\mathrm{PM}_{10}\right)$ were calculated using estimates for the resistances $R_{\mathrm{a}}, R_{\mathrm{b}}$, and $R_{\mathrm{c}}$ for each hour throughout a "base year" (Scott et al. 1998). Hourly meteorological data and pollutant concentrations were obtained from local monitoring stations in the Denver metropolitan area for 1999, when pollutant concentrations were near average.

Energy savings result in reduced emissions of criteria air pollutants (volatile organic hydrocarbons [VOCs], $\mathrm{NO}_{2}, \mathrm{SO}_{2}$, $\mathrm{PM}_{10}$ ) from power plants and space-heating equipment. These avoided emissions were calculated using utilityspecific emission factors for electricity and heating fuels.

Emissions of biogenic volatile organic compounds (BVOCs) from the green ash were included in the analysis because of their impact on ozone formation. The hourly emission rates of isoprene $(0.04 \mu \mathrm{g} / \mathrm{g} / \mathrm{hr})$, monoterpene $(0.04 \mu \mathrm{g} /$ $\mathrm{g} / \mathrm{hr})$, and other VOCs $(0.12 \mu \mathrm{g} / \mathrm{g} / \mathrm{hr})$ were adjusted for temperature (monoterpene) or for sunlight and temperature (isoprene) (Winer et al. 1998). This approach did not account for the benefit associated with lowered summertime air temperatures and the resulting reduced hydrocarbon emissions from anthropogenic and biogenic sources.

The monetary value of tree effects on air quality should reflect the value that society places on clean air as indicated by its willingness to pay for pollutant reductions. Lacking specific data for Fort Collins, air quality benefits were monetized as damage values (Table 1) using regression relationships between emission values, pollutant concentrations, and population numbers (Wang and Santini 1995). This regression provides estimates of the costs of damages to human health resulting from air pollution.

\section{Stormwater Runoff Reductions}

A numeric interception model accounted for the amount of annual rainfall intercepted by trees as well as throughfall and stem flow (Xiao et al. 2000). The volume of water stored in tree crowns was calculated from tree crown leaf and stem surface areas and water depth on these surfaces. Hourly meteorological and rainfall data for 1998 in Fort Collins were used because total rainfall was close to the average annual amount (458 mm versus historic mean of $452 \mathrm{~mm}, 18.3$ in versus $18.1 \mathrm{in})$. Stormwater reduction benefits were priced by estimating costs of controlling stormwater runoff with retention/detention basins in Fort Collins. Total expenditures for retention/detention basin land acquisition, construction, and annual maintenance and operation costs for 20 years were 
\$1.21 million. Assuming that the typical basin was designed to hold $21,216 \mathrm{~m}^{3}(17.2 \mathrm{ac} \mathrm{ft})$ of runoff and filled once annually for 20 years, the control cost was $\$ 2.85 / \mathrm{m}^{3}$ (\$0.0108/gal) (K. McBride, pers. comm.).

\section{Aesthetics and Other Benefits}

Many benefits attributed to urban trees are difficult to price (e.g., beautification, privacy, wildlife habitat, sense of place, well-being). However, the value of some of these benefits can be captured in the differences in sales prices of properties with and without trees. Anderson and Cordell (1988) found that each large front-yard tree was associated with a $0.88 \%$ increase in sales price. In this analysis, aesthetic $(A)$ benefits (\$/tree/year) are expressed for a single tree as:

$$
A=L \times P
$$

where $L$ is the annual increase in tree leaf area (LA) and $P$ is the adjusted price $\left(\$ / \mathrm{m}^{2} \mathrm{LA}\right)$ :

$$
P=(T \times C) / M
$$

where

$$
\begin{aligned}
T= & \text { large tree contribution to home sales price }=0.88 \% \times \\
& \text { median sales price } \\
C= & \text { tree location factor }(\%) \text { that depreciates the benefit } \\
& \quad \begin{array}{l}
\text { for trees in side or backyards or outside of residential } \\
\text { areas }
\end{array} \\
M= & \text { large tree leaf area. }
\end{aligned}
$$

To illustrate the sensitivity of the tree's overall benefitbased value to $T$, benefits were calculated using the median sales prices for single-family homes in Fort Collins $(\$ 212,000)$ and nearby Boulder $(\$ 413,000)$ (McPherson et al. 2005a). The values for $C$ and $M$ were 1.0 and $675 \mathrm{~m}^{2}(7,290$ $\mathrm{ft}^{2}$ ), respectively, in both cities. All other benefits were assumed to be the same for Boulder and Fort Collins.

\section{RESULTS-SINGLE-TREE EXAMPLE}

Estimates of tree value using the trunk formula method increased from $\$ 154$ at year 1 to $\$ 1,910$ at year 20 and $\$ 5,807$ at year 40 when dbh was projected to reach $51 \mathrm{~cm}$ (20.4 in) (Figure 2). The cumulative value of benefits produced by the tree followed a similar trend, although the relative rate of increase slowed with age compared with values calculated with the trunk formula. At year 20, cumulative benefits totaled $\$ 1,023$ and at year 40 , they totaled $\$ 3,102$. After 40 years, benefit-based values were $53 \%$ of cost-based values in Fort Collins. However, this percentage was $86 \%$ for the tree in Boulder as a result of the higher residential median sales price, nearly double that of Fort Collins.

In Fort Collins, two-thirds or more of total benefits were attributed to aesthetic and other benefits (Figure 3). The rate of increase of the aesthetic benefit slowed with age because it

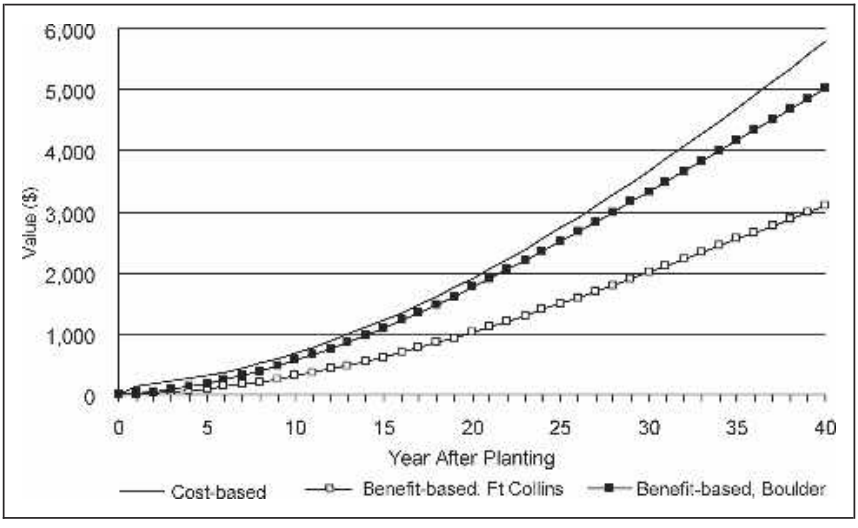

Figure 2. Value of a green ash in Fort Collins estimated by the trunk formula (cost-based) and benefit-based approaches. The Boulder values assumed a median home sales price nearly twice that in Fort Collins.

is driven by annual change in leaf surface area. Although total leaf area increased with tree age, the annual rate of increase slowed after the first few years. On the other hand, cost-based value increased as a function of dbh and resulting trunk area, explaining slightly higher rates of increase throughout the 40 years relative to benefit-based values. These differences in ways of mathematically expressing growth patterns (i.e., leaf area versus dbh) were largely responsible for the different rates of increase seen in Figure 2.

Over the 40 year period, aesthetic and other benefits totaled $\$ 2,025(65 \%)$. Runoff reduction benefits resulting from rainfall interception totaled $\$ 476(15 \%)$, energy savings were $\$ 280$ (9\%), net air quality benefits were valued at \$243 (8\%), and $\mathrm{CO}_{2}$ reductions were $\$ 78(3 \%)$.

\section{DISCUSSION-SINGLE-TREE EXAMPLE}

An attractive feature of the benefit-based approach to tree valuation is that the relative contribution of different benefits

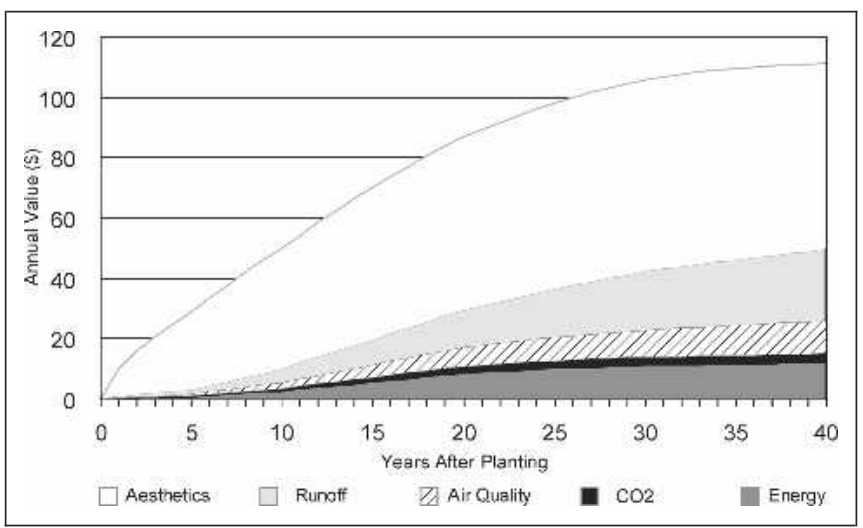

Figure 3. Projected annual benefits for the green ash in Fort Collins. 
can be observed. Although in this example, benefit-based estimates of value were less than cost-based estimates, a more complete accounting of tree benefits will narrow this gap. Research that identifies, quantifies, and monetizes other benefits such as effects of trees on human health and well-being and on the vitality of commercial areas is critical to future application of benefit-based valuation (see Social Aspects of Urban Forestry Special Issue, Journal of Arboriculture, May 2003).

The benefit-based approach is similar to the cost-based approach in that tree species and location are important terms that can be explicitly defined. The same green ash tree located opposite a south-facing wall would produce less energy savings and associated air quality benefits than the tree opposite a west-facing wall. This difference is easily obtained with the benefit-based approach, and is considered, although less directly, in the cost-based calculations in the terms for placement and contribution rating.

Tree condition is directly included in the cost-based method but not used in the benefit-based approach. This is an important limitation because the production of current and future benefits should be directly linked to tree health as well as tree size. As currently calculated, green ash benefits reflect the dimensions and health of the Fort Collins sample street tree population on which this study was based, not any single tree. Another limitation to estimating the future stream of benefits with the benefit-based approach is uncertainty as to tree longevity. Published data on the typical lifespans of trees in different regions and growing conditions are scarce. Nevertheless, several tree valuation approaches do include life expectancy (Watson 2002, Randrup 2005).

Particularly in cities outside the United States, multistory buildings may contain retail commercial uses at ground level and residential uses above. Benefits produced by a tree in front of the building can influence several property owners in different ways depending on the types of heating and cooling equipment, energy use patterns, and property values. This issue is under investigation in Lisbon, Portugal.

\section{METHODS-MULTITREE EXAMPLE}

This real-world example involves five Chinese pistache (Pistacia chinensis) street trees planted 15 years ago (1990) along Antelope Drive in Davis, California. It asks three questions:

1. How do cost-based estimates of tree value compare with benefit-based estimates?

2. Using the benefit-based approach, can we determine if it is cost-effective to remove and replace these trees in a more suitable site nearby?

3. Using the benefit-based approach, can we determine how much money would have been saved if the trees had been planted in the better site originally?

\section{Cost Approach}

The five trees were measured and appraised following procedures outlined in the Guide for Plant Appraisal (Council of Tree \& Landscape Appraisers 2000) with advice from Dr. Richard Harris (University of California, Davis), who has led development of this approach. The trees were located in a quiet, residential neighborhood adjacent to a parking lot for condominium units and across from single-family houses (Figure 4). The trees were located in a 46 to $92 \mathrm{~cm}$ (18.4 to 36.8 in) strip between the mountable curb and sidewalk. They did not appear to be irrigated, although excess irrigation could run into the planting strip from the shrub bed across the sidewalk. The trees were of similar size (dbh ranging from 21 to $25 \mathrm{~cm}$ [8.4 to $10 \mathrm{in}$ ]) and condition ( $48 \%$ to $64 \%$; Table 2 ) with the exception of tree 5 , which exhibited symptoms of stress. Location ratings were the same for each tree: $80 \%$, $70 \%$, and $50 \%$ for site, contribution, and placement, resulting in an overall location rating of $67 \%$. The location rating reflected the attractive and relatively high market value of the area, the important functional and aesthetic contributions of the pistache trees on this residential street, and their unfavorable placement in a narrow strip that limited tree growth, led to curb and sidewalk damage, and increased tree and infrastructure management costs.

A species rating of $90 \%$ for Chinese pistache was obtained from data for the Northern California Interior Valley in the Regional Supplement (WC-ISA 2004). The unit cost for the largest transplantable tree (24 in box, \$173) was $\$ 11.94 / \mathrm{cm}^{2}$ TA $\left(\$ 77.04 / \mathrm{in}^{2}\right)$ and the installed cost was $\$ 345$ per tree.

\section{Benefit Approach}

In this example, the future streams of benefits and costs are estimated and net benefits are calculated by subtracting total

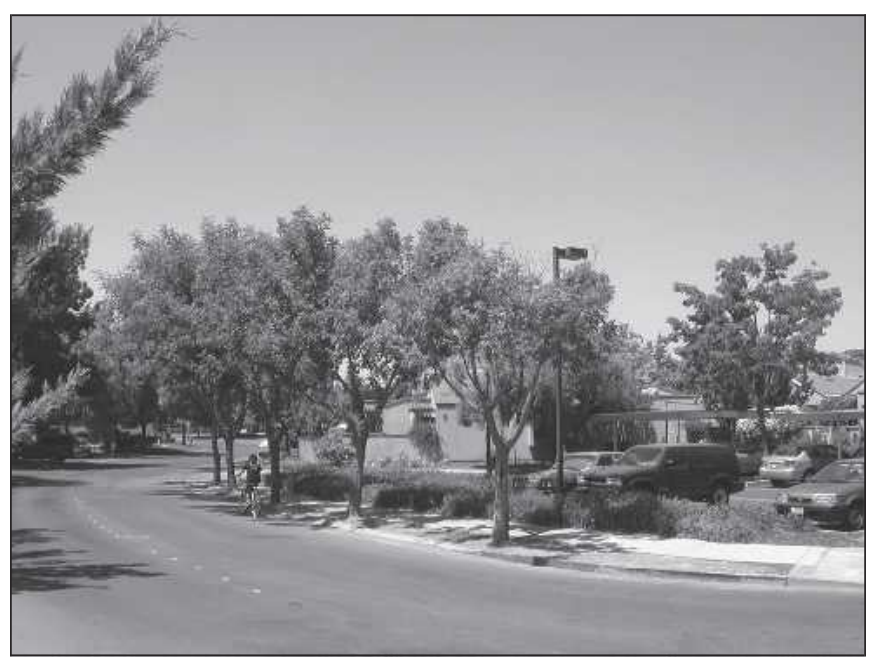

Figure 4. Streetside location of the five pistache trees as well as the shrub bed to the right where replanting was considered. Tree number 5 is closest to the camera station. 
Table 2. Appraised values and related information for each pistache tree.

\begin{tabular}{|c|c|c|c|c|c|c|}
\hline & Tree 1 & Tree 2 & Tree 3 & Tree 4 & Tree 5 & Average \\
\hline $\mathrm{dbh}(\mathrm{cm})$ & 21.0 & 24.3 & 22.2 & 22.9 & 24.9 & 23.1 \\
\hline Trunk area $\left(\mathrm{cm}^{2}\right)$ & 347 & 462 & 388 & 410 & 486 & 419 \\
\hline Condition (\%) & 56 & 56 & 64 & 60 & 48 & 57 \\
\hline Appraised value (\$) & 1,451 & 1,913 & 1,848 & 1,824 & 1,720 & 1,751 \\
\hline
\end{tabular}

Unit cost $=\$ 11.94 / \mathrm{cm}^{2} \mathrm{TA}$, installed cost $=\$ 345$, species $=90 \%$, location $=66.7 \%$.

dbh, trunk diameter at breast height.

future costs from benefits. Additionally, the cost-effectiveness of removing and replanting the pistache trees in a nearby shrub bed, where they would not damage the sidewalk and curb, is examined.

\section{Benefit Estimation}

Benefits were calculated using the same numeric modeling methods described earlier. Tree growth data, however, were for pistache street trees in Modesto, California, a Central Valley city with a climate similar to Davis (Figure 1; Peper et al. 2001). Environmental benefits were calculated by dbh class for pistache in Modesto using local geographic data (e.g., air pollutant concentrations, hourly climate, building types) (McPherson et al. 1999). Benefits were monetized based on information specific to Davis (Table 1, Maco and McPherson 2003). For more detailed information on modeling and monetizing benefits in Modesto and Davis, see McPherson et al. (1999) and Maco and McPherson (2003).

\section{Cost Estimation}

Past and future expenditures for tree planting and care were based on the cost of street tree services in Davis (Loux 2002; Maco and McPherson 2003; R. Cain, pers. comm.). Planting costs for a \#15 tree averaged $\$ 75$ per pistache, and replanting included $\$ 50$ per tree to prepare the shrub bed (Table 3).

Table 3. Costs for tree maintenance and sidewalk, curb, and gutter repair.

\begin{tabular}{lr}
\hline Activity & \$/tree \\
\hline Plant pistache & 75 \\
Plant replacement (add \$50 for site prep of shrub bed) & 125 \\
Prune small tree (4 year cycle) & 36 \\
Prune 15-30 cm dbh (8 year cycle) & 113 \\
Prune 31-45 cm dbh (8 year cycle) & 163 \\
Prune 46-60 cm dbh (8 year cycle) & 225 \\
Remove pistache (15-30 cm dbh at 15 years) & 150 \\
Grind sidewalk (5 squares at years 10, 15, 30, and 35) & 20 \\
Root prune (at years 20 and 40) & 30 \\
Remove and replace sidewalk (at years 20 and 40) & 576 \\
Remove and replace curb/gutter (at years 20 and 40) & 600 \\
\hline
\end{tabular}

dbh, trunk diameter at breast height.
Small trees $(<15 \mathrm{~cm}$ dbh [6 in]) were pruned on a 4 year cycle at a cost of $\$ 36$ per tree. Larger trees were pruned on 8 year cycles (Table 3 ). Removal costs for the 15 year old pistache trees (23 cm dbh [9 in]) were $\$ 150$ per tree. Program expenditures could not be directly determined by size class for storm cleanup, liability (i.e., trip-and-fall and property damage payments), or administration (i.e., supervisory and clerical staff salaries, training, supplies). To estimate costs per centimeter of $\mathrm{dbh}$ for these categories, first, the total annual expenditures were divided by total tree numbers to derive average annual costs per tree $(\$ 1.21$ for storm cleanup/ liability and $\$ 3.33$ for administration). Next, it was assumed that per-tree costs for these services increase proportionally to $\mathrm{dbh}$. Therefore, average annual costs per centimeter dbh were calculated as $\$ 0.04 / \mathrm{cm}(\$ 0.11 /$ in) for storm cleanup/liability and $\$ 0.12 / \mathrm{cm}(\$ 0.31 / \mathrm{in})$ for administration by dividing by the population's average dbh of $27.6 \mathrm{~cm}$ (11.4 in).

Expenditures for curb and sidewalk repairs resulting from tree damage caused by the pistache trees were obtained from Davis's Public Works Department (S. Knopf, pers. comm.). Grinding the joints of lifted sidewalk squares reduces the tripping hazard and is less expensive than removal and replacement. Grinding is a temporary measure because it can only be repeated several times before the concrete becomes too thin to serve as a reliable walking surface. The joints of sidewalks near the pistache trees were ground 5 years ago (year 10) and will be ground again this year (year 15). This cycle was assumed to be repeated with five joints ground (one per tree) at years 30 and 35 (Table 3). The sidewalk and curb were projected to be removed and replaced at years 20 and 40 as a result of heaving by the pistache trees.

Sidewalk grinding costs were $\$ 20$ per $1.2 \mathrm{~m}$ (4 ft) joint, and typically one joint was heaved and ground per tree (Table 3 ). Tree roots were pruned before repouring the curb and sidewalk at a cost of $\$ 30$ per tree during years 20 and 40 . Each sidewalk square measured $1.2 \times 1.2 \mathrm{~m}(4 \times 4 \mathrm{ft})$ and the cost for removal and replacement was $\$ 128 / \mathrm{m}^{2}\left(\$ 12 / \mathrm{ft}^{2}\right)$ or $\$ 576$ per tree assuming three squares were replaced per tree $(\mathrm{S}$. Knopf, pers. comm.). Curb and gutter replacement costs were $\$ 162 / \mathrm{m}(\$ 50 / \mathrm{ft})$ or $\$ 600$ per tree assuming $3.7 \mathrm{~m}(12.2 \mathrm{ft})$ per tree. 


\section{Discounting}

The future stream of benefits (income) and expenses was converted into present value through capitalization or discounting (Council of Tree \& Landscape Appraisers 2000). The discount rate incorporates the time value of money and inflation. The former refers to the fact that a dollar received in the future is worth less than one received in the present, because the present dollar can earn interest. Inflation is the anticipated escalation in prices over time, which is assumed to be the same for benefits and costs in this analysis. Selecting a discount rate is problematic because the cost of capital is different for a municipality than for a resident or business. Generally, higher discount rates are associated with lower net present values (NPV) of investments in tree planting because most costs are incurred during the first years when trees are planted, whereas most benefits occur later as the trees mature and are discounted heavily. To assess how these findings change in response to different discount rates, results are presented using rates of $0 \%, 4 \%, 7 \%$, and $10 \%$. NPV estimates (present value of benefits minus present value of costs) can be interpreted as yield on the investment in excess of the cost of capital. The benefit-cost ratio is the ratio of the present value of benefits and costs.

\section{RESULTS-MULTITREE EXAMPLE}

\section{Comparing Cost- and Benefit-Based Tree Values}

The first question addressed was "How do cost-based estimates of tree value compare with benefit-based estimates?" The cost-based appraised value of the five trees was $\$ 8,756$ with the average amount $\$ 1,751$ per tree (Table 2). The benefit-based NPVs for the five trees were negative at all discount rates, ranging from $\$-6,481(0 \%)$ to $\$-1,129$ (10\%) (Table 4, retain scenario). Contrary to normal, NPVs increased (were less negative) with higher discount rates, primarily because sizable future curb and sidewalk replacement expenditures at years 20 and 40 were heavily discounted relative to future benefits.

Without discounting, total annual benefits ranged from $\$ 50$ to $\$ 90$ per tree with the majority attributed to aesthetics/

Table 4. Present values (PVs) for two scenarios: retain trees or remove and replant five pistache trees in nearby shrub bed, years 16 to $\mathbf{4 0}$

\begin{tabular}{|c|c|c|c|c|c|c|}
\hline \multirow[b]{2}{*}{$\begin{array}{l}\text { Discount } \\
\text { rate }(\%)\end{array}$} & \multicolumn{2}{|c|}{ PV Benefits } & \multicolumn{2}{|c|}{ PV Costs } & \multicolumn{2}{|c|}{ Net PV } \\
\hline & Retain & $\begin{array}{l}\text { Remove/ } \\
\text { replace }\end{array}$ & Retain & $\begin{array}{l}\text { Remove/ } \\
\text { replace }\end{array}$ & Retain & $\begin{array}{l}\text { Remove/ } \\
\text { replace }\end{array}$ \\
\hline 0 & 8,629 & 8,625 & 15,109 & 9,194 & $-6,481$ & -569 \\
\hline 4 & 5,696 & 4,844 & 8,737 & 8,096 & $-3,041$ & $-3,252$ \\
\hline 7 & 4,407 & 3,310 & 6,221 & 7,559 & $-1,814$ & $-4,249$ \\
\hline 10 & 3,543 & 2,355 & 4,672 & 7,159 & $-1,129$ & $-4,803$ \\
\hline
\end{tabular}

others and energy savings. Cumulative annual benefits increased steadily to a peak $\$ 1,720$ per tree at 40 years. Costs peaked at $\$-3,022$ per tree at 40 years (Figure 5). Total annual costs were typically $\$ 4$ to $\$ 6$ per tree but jumped to $\$ 170, \$ 190$, and $\$ 1,200$ per year when tree care and infrastructure repair activities were projected to occur. Without discounting, total benefits for all five trees over 25 years (years 16 to 40 ) were $\$ 8,629$ ( $\$ 1,726 /$ tree), surprisingly similar to the appraised value. However, expenditures totaled $\$ 15,109$ ( $\$ 3,022 /$ tree), resulting in a negative net value of $\$-6,481$ (\$-1,296/tree) (Table 4). Even heavy discounting of future costs did not produce a positive NPV.

In this example, the cost-based estimate of value was approximately two to five times greater than the benefit-based estimate. Substantial future sidewalk expenditures included in the benefit-based approach magnified the difference between results. From the sidewalk manager's perspective, the cost-based approach may not provide the most reasonable indication of value. Replacement cost does not incorporate future costs, which were projected to be substantial. Therefore, in situations such as this, the benefit-based approach can be a good tool for testing and adjusting the reasonableness of a cost-based estimate of value.

\section{Cost-Effectiveness of Removal and Replacement versus Tree Retention}

The second question addressed in this article was, "Using the benefit-based approach, can we determine if it is costeffective to remove and replace these trees in a more suitable site nearby?" Removing and replacing the pistache trees in the nearby shrub bed, where there is ample room to grow, incurs short-term costs but avoids sidewalk and curb repair costs during the next 25 years. Benefits from the smaller transplants will be less than from the existing pistache $(23 \mathrm{~cm}$

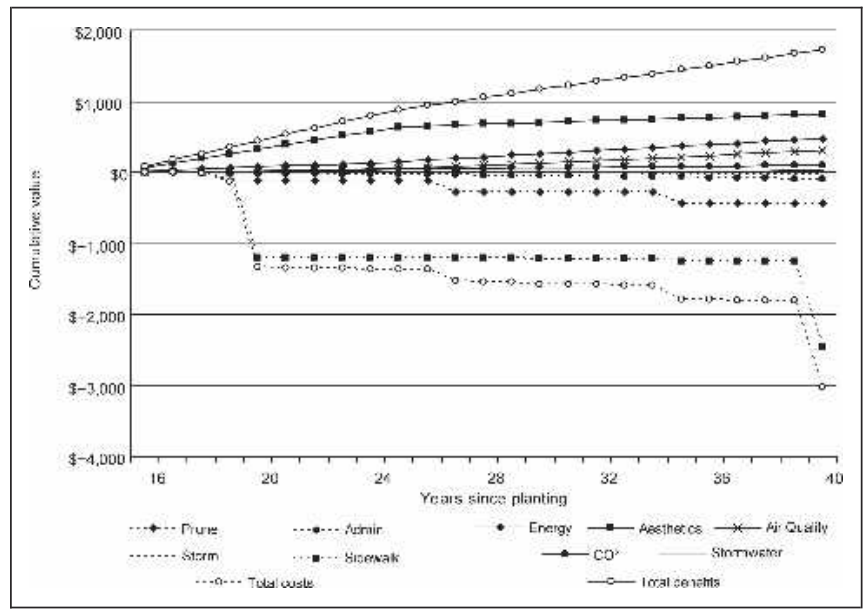

Figure 5. Average cumulative benefits and costs per streetside pistache tree ( $0 \%$ discount rate), years 16 to 40 . 
[9.2 in] dbh). In reality, a number of other factors would be involved in a decision to remove and replace these trees such as attitudes of local residents and availability of resources. However, the economic criterion for such a decision is straightforward: the most cost-effective strategy would have the highest NPV of benefits.

Removal and replacement was not a cost-effective strategy at $7 \%$ and $10 \%$ discount rates (Table 4 and Figure 6). At higher discount rates, it was more cost-effective to retain the trees for the next 25 years, primarily because future infrastructure repair costs were relatively heavily discounted. For example, at the $10 \%$ rate, the NPV was $\$-4,803$ for removing and replacing the five trees and $\$-1,129$ for retaining the trees. NPVs were similar at the $4 \%$ discount rate, whereas the choice to remove/replace was clearly most cost-effective assuming no discounting. In the latter case, net benefits totaled $\$-569$ for the remove/replace option versus $\$-6,481$ for maintaining the status quo. At lower discount rates, future infrastructure repair expenditures were less heavily discounted, making the tree retention option relatively less costeffective.

Expenditures for the tree retention scenario totaled $\$ 15,109$ over 25 years $(0 \%)$ and were discounted at $10 \%$ to only $\$ 4,672$. Approximately one-third of the total expenditure was heavily discounted because it occurred at year 40 when sidewalks, curb, and gutter were replaced (Figure 6).

In contrast, expenditures for the remove/replace scenario were largely up-front and less heavily discounted; $\$ 9,194$ at $0 \%$ was discounted to $\$ 7,159$ at $10 \%$. Initial costs for removal, site preparation, and planting the five pistache trees were $\$ 1,375$. Added to this was $\$ 5,880$ for removing and replacing sidewalk and curb and gutter, assumed to occur at the time of tree removal. Hence, initial costs for remediation and planting totaled $\$ 7,255$, or $79 \%$ of the projected 25 year total expenditure.

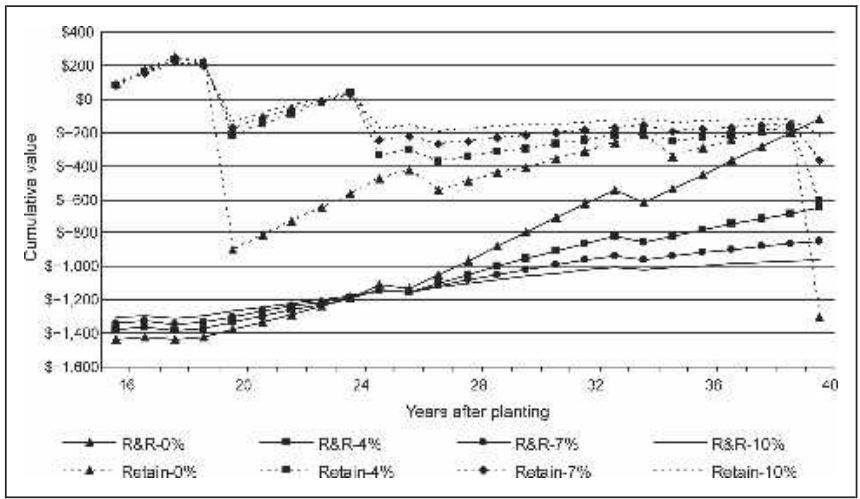

Figure 6. Average cumulative net present value of benefits per pistache tree at different discount rates for two scenarios (retain existing tree or remove and replant (R\&R) in shrub bed) for years 16 to 40 .
The importance of discounting on cost-effectiveness was apparent when considering the stream of benefits as well as expenditures. Total undiscounted benefits were nearly identical for both scenarios $(\$ 8,629$ and $\$ 8,625)$, but at a $10 \%$ discount rate, the PV of benefits was $\$ 3,543$ for the tree retention scenario and $\$ 2,355$ for the remove/replace option. With the tree retention scenario, benefits decreased as tree growth slowed, whereas benefits increased with time for the more rapid growing transplants in the remove/replace scenario. As a result, remove/replace scenario benefits were more heavily discounted.

In summary, the most cost-effective decision depends on the manager's discount rate. However, it is important to note that NPVs were negative for both scenarios and at all discount rates, indicating that the decision to plant this species in this location was ill-advised in the first place.

\section{Cost-Effectiveness of Initially Planting Pistache in Shrub Bed}

The final question addressed in this article was, "Using the benefit-based approach, can we determine how much money would have been saved if the trees had been planted in the better site originally?" The analysis compared the 40 year stream of benefits and costs for the current scenario with planting the same species in the nearby shrub bed. Tree growth and resulting benefits were assumed to be the same for both scenarios, although trees in the more spacious shrub bed were likely to grow faster than ones in the more restricted streetside location. Any differences in benefits are difficult to predict. Trees in the shrub bed will shade less street surface than streetside trees, and increased street shade has been related to improved pavement condition and reduced repaving expense (McPherson and Muchnick 2005). Trees in the shrub bed, however, will shade more of the parking lot to the north. Shading parked cars can reduce evaporative hydrocarbon emissions that are involved in ozone formation (Scott et al. 1999). Given these uncertainties, this analysis assumed that benefits were held constant and focused on how differences in expenditures influenced cost-effectiveness.

Not surprisingly, choosing to plant the five pistache in the shrub bed was far more cost-effective than planting them streetside (Table 5). NPVs for the shrub bed planting ranged from $\$ 1,578(10 \%)$ to $\$ 8,695(0 \%)$, whereas NPVs for the current location ranged from $\$-3,765(0 \%)$ to $\$ 476(10 \%)$. Savings associated with planting in the shrub bed ranged from $\$ 1,102$ (10\%) to $\$ 12,460(0 \%)$, or $\$ 220$ to $\$ 2,492$ per tree.

Nondiscounted benefits for both scenarios totaled $\$ 12,824$, but expenditures were four times greater for the streetside location $(\$ 16,589)$ compared with the shrub bed site $(\$ 4,129)$ (Figure 7). NPVs increased with discount rate for the streetside planting but decreased with increasing discount rate for the shrub bed planting. This finding reflects heavy discount- 
Table 5. Present values (PVs) for two scenarios: plant five pistache trees in current streetside location or plant in nearby shrub bed, years 1 to 40 .

\begin{tabular}{|c|c|c|c|c|c|c|}
\hline \multirow{2}{*}{$\begin{array}{l}\text { Discount } \\
\text { rate }(\%)\end{array}$} & \multicolumn{2}{|c|}{ PV benefits } & \multicolumn{2}{|c|}{ PV costs } & \multicolumn{2}{|c|}{ Net PV } \\
\hline & Street & Shrub & Street & Shrub & Street & Shrub \\
\hline 0 & 12,824 & 12,824 & 16,589 & 4,129 & $-3,765$ & 8,695 \\
\hline 4 & 6,012 & 6,012 & 6,158 & 1,971 & -147 & 4,041 \\
\hline 7 & 3,780 & 3,780 & 3,386 & 1,315 & 394 & 2,464 \\
\hline 10 & 2,552 & 2,552 & 2,075 & 974 & 476 & 1,578 \\
\hline
\end{tabular}

ing of infrastructure repair costs projected to occur later in the time horizon for the streetside planting. This example illustrates that the decision where to plant the trees has a profound economic impact on their future value.

\section{CONCLUSIONS}

One purpose of this study was to compare estimates of tree value obtained using cost- and benefit-based approaches. In the single-tree example, values at 40 years after planting a green ash were $\$ 5,807$ using the cost-based approach and $\$ 3,102$ in Fort Collins and $\$ 5,022$ in Boulder using the benefit-based approach. This example did not include tree planting and management costs and thus was not a full accounting of net benefits. It illustrated how the benefit-based approach reveals the magnitude of benefits by type and can explicitly reflect effects of tree location on benefits such as energy savings. When tree care costs are relatively small, estimates of the PV of future benefits alone may track cost-based estimates of value. In such cases, benefit-based values are another way to assess fairness and reasonableness of cost-based appraisals.

For five pistache trees in Davis, California, the total appraised value 15 years after planting was $\$ 8,756$. Assuming 25 years of continued growth, the undiscounted cumulative value of benefits was $\$ 8,629$, very similar to the cost-based

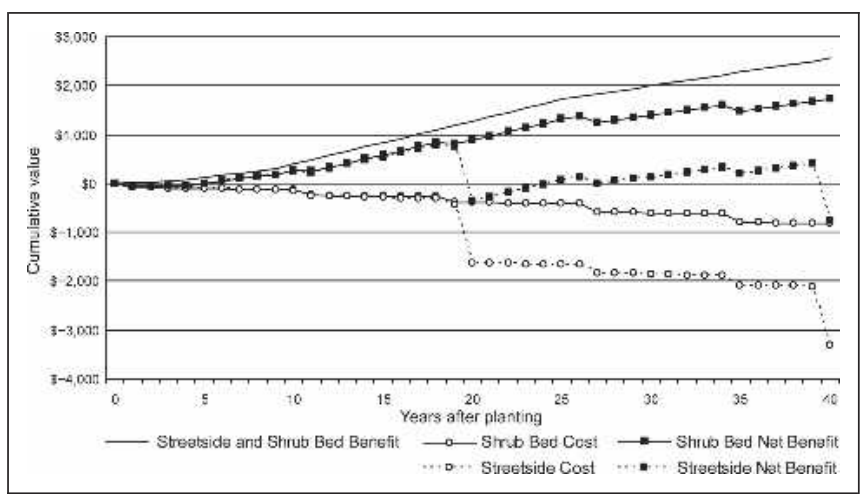

Figure 7. Average cumulative benefits, costs, and net benefits per pistache $(0 \%$ discount rate) for two scenarios, planting streetside and in shrub bed, years 1 to 40 . Benefits were the same for both scenarios. estimate. However, adding the projected cost stream and discounting resulted in negative NPVs that ranged from $\$-6,481$ (0\% discount rate) to $\$-1,129$ (10\%). Negative NPVs reflect future infrastructure repair costs projected to be well in excess of benefits. The benefit-based approach can capture this relationship, whereas the cost-based approach cannot.

Another purpose of this study was to examine the use of the benefit-based approach as a decision support tool for design and management. Municipal arborists are frequently faced with choices regarding which species to plant where and whether to retain existing trees or remove and replace them. These questions were answered in the multitree example using the benefit-based approach. Removing and replacing the five pistache street trees was not cost-effective at $7 \%$ and $10 \%$ discount rates, primarily because high future infrastructure repair costs associated with retaining the trees were heavily discounted. At the lower discount rates, the tree removal and replacement option became relatively more costeffective.

Planting the five pistache trees in their current location was not an economically sound decision, because NPVs calculated for 40 years after planting ranged from $\$-3,765(0 \%)$ to $\$ 476(10 \%)$. Planting the same trees in a nearby shrub bed would have saved a substantial amount of money, because NPVs ranged from $\$ 1,578(10 \%)$ to $\$ 8,695(0 \%)$. Hence, by accounting for future costs as well as benefits, the benefitbased approach can help landscape architects and municipal foresters evaluate the long-term economic implications of tree planting and management decisions. Putting this knowledge to work will help ensure that our investments in green infrastructure keep paying us back.

\section{LITERATURE CITED}

Anderson, L.M., and H.K. Cordell. 1988. Residential property values improve by landscaping with trees. Southern Journal of Applied Forestry 9:162-166.

Cassel, W. (Ed.). 2004. Regional Plant Information. International Society of Arboriculture, Rocky Mountain Chapter. Denver, CO.

CO2e.com. 2002. Market Size and Pricing. Accessed via the World Wide Web. http://www.co2e.com/stratagies/ AdditionalInfo.asp?PageID = 273\#1613 (accessed 10/23/ 02).

Council of Landscape \& Tree Appraisers. 2000. Guide for Plant Appraisal (9th ed.). International Society of Arboriculture, Champaign, IL.

Cullen, S. 2000. Tree appraisal: What is the trunk formula method (9th ed.)? http://www.tree-tech.com/cullentf.shtml (accessed 3/28/02). Arboricultural Consultant Summer: 7-8.

2002. Tree appraisal: Can depreciation factors be rated greater than $100 \%$ ? Journal of Arboriculture 28: 153-158. 
2005. Tree appraisal: Chronology of North American industry guidance. Journal of Arboriculture 31: 157-162.

Loux, K.D. 2002. City of Davis, Community Forest Management Plan. City of Davis, Parks and Community Services Department. Davis, CA.

Maco, S.E., and E.G. McPherson. 2003. A practical approach to assessing structure, function, and value of street tree populations in small communities. Journal of Arboriculture 29:84-97.

McPherson, E.G., and J. Muchnick. 2005. Effects of street tree shade on asphalt concrete pavement performance. Journal of Arboriculture 31:303-310.

McPherson, E.G., and J.R. Simpson. 1999. Carbon Dioxide Reductions Through Urban Forestry. General Technical Report PSW-171. USDA Forest Service, Pacific Southwest Research Station. Albany, CA.

McPherson, E.G., J.R. Simpson, P.J. Peper, S. Gardner, K. Vargas, J. Ho, and Q. Xiao. 2005a. City of Boulder, Colorado Municipal Tree Resource Analysis. Internal Technical Report. Center for Urban Forest Research, USDA Forest Service, Pacific Southwest Research Station. Davis, CA.

McPherson, E.G., J.R. Simpson, P.J. Peper, S.E. Maco, and Q. Xiao. 2005b. Municipal forest benefits and costs in five U.S. cities. Journal of Forestry 103:411-416.

McPherson, E.G., J.R. Simpson, P.J. Peper, S.E. Maco, Q. Xiao, and P.J. Hoefer. 2003. Northern Mountain and Prairie Community Tree Guide. Center for Urban Forest Research, USDA Forest Service, Pacific Southwest Research Station. Davis, CA.

McPherson, E.G., J.R. Simpson, P.J. Peper, and Q. Xiao. 1999. Benefit-cost analysis of Modesto's municipal urban forest. Journal of Arboriculture 25:235-248.

Peper, P.J., E.G. McPherson, and S.M. Mori. 2001. Equations for predicting diameter, height, crown width, and leaf area of San Joaquin Valley street trees. Journal of Arboriculture 27:306-317.

Pillsbury, N.H., J.L. Reimer, and R.P. Thompson. 1998. Tree volume equations for fifteen urban species in California. Technical Report 7. Urban Forest Ecosystems Institute, California Polytechnic State University. San Luis Obispo, CA.

Randrup, T.B. 2005. Development of a Danish model for plant appraisal. Journal of Arboriculture 31:114-123.

Scott, K.I., E.G. McPherson, and J.R. Simpson. 1998. Air pollutant uptake by Sacramento's urban forest. Journal of Arboriculture 24:224-234.

Scott, K.I., J.R. Simpson, and E.G. McPherson. 1999. Effects of tree cover on parking lot microclimate and vehicle emissions. Journal of Arboriculture 25:129-142.
Tyrvainen, L. 2001. Economic valuation of urban forest benefits in Finland. Journal of Environmental Management 62:75-92.

Wang, M.Q., and D.J. Santini. 1995. Monetary values of air pollutant emissions in various U.S. regions. Transportation Research Record 1475:33-41.

Watson, G. 2002. Comparing formula methods of tree appraisal. Journal of Arboriculture 28:11-18.

WC-ISA. 2004. Species Classification and Group Assignment. Western Chapter, International Society of Arboriculture. Cohasset, CA.

Winer, A.M., J. Karlik, J. Arey, Y. Chung, and A. Reissell. 1998. Biogenic Hydrocarbon Inventories for California: Generation of Essential Databases. Final Report, California Air Resources Board Contract No. 95. Sacramento, CA.

Xiao, Q., E.G. McPherson, S.L. Ustin, and M.E. Grismer. 2000. A new approach to modeling tree rainfall interception. Journal of Geophysical Research 105:29173-29188.

\section{E. Gregory McPherson}

Director, Center for Urban Forest Research

USDA Forest Service

Pacific Southwest Research Station

clo Department of Plant Science, MS-6

One Shields Avenue

University of California

Davis, CA 95616, U.S.

gmcpherson@fs.fed.us

Résumé. L'évaluation des arbres basée sur les bénéfices permet d'obtenir des estimés alternatifs quant à une valeur raisonnable et honnête pour des arbres, et ce tout en illustrant la contribution relative des différents types de bénéfices. Cette étude compare des estimations de la valeur des arbres obtenues à partir d'une approche basée sur le coût et d'une approche basée sur les bénéfices. L'approche à partir des coûts fait appel à la méthode de la surface terrière développée par le CTLA (Council of Trees and Landscape Appraisers) et l'approche sur la base des bénéfices fait appel à un calcul de la valeur actuelle nette - bénéfices totaux futurs auxquels sont soustraits les coûts escomptés jusqu'au présent - des bénéfices futurs et des coûts au moyen de données de croissance des arbres et de modèles numériques. Dans un exemple hypothétique, la valeur d'un frêne de Pennsylvanie (Fraxinus pennsylvanica) de 40 ans a été établi à $5807 \$$ par l'approche du coût, et $3102 \$$ (pour un arbre poussant à Fort Collins au Colorado) ou 5022\$ (pour un arbre poussant Boulder au Colorado) au moyen de l'approche sur la base des bénéfices. Néanmoins, cet exemple n'a pas pris en considération les coûts de plantation et de gestion. Dans le cadre d'un exemple pour des arbres multiples avec cinq pistachiers (Pistacia chinensis) de rue de 15 ans à Davis en Californie, la méthode de la surface terrière (sur la base du coût) a donné une valeur de 8756 alors que celle obtenue par l'approche des bénéfices s'est avérée négative, et ce à partir de taux d'escompte entre 0 et $10 \%$. Des valeurs négatives sur la base 
des bénéfices se produisent du fait que les coûts futurs de réparation du trottoir ont été projetés à des valeurs excédants celles des bénéfices, une relation non complètement incluse avec l'approche sur la base du coût pour l'évaluation. L'abattage et le remplacement des cinq pistachiers de rue n'était pas efficace à des taux d'escompte entre 7 et $10 \%$, et ce principalement en raison du fait que les coûts élevés futurs de réparation du trottoir associés avec la préservation des arbres ont été lourdement escomptés. La plantation de cinq pistachiers dans leur emplacement actuel n'était pas une décision économiquement sage, mais leur plantation dans un massif d'arbustes adjacent aurait permis d'économiser 1102\$ (10\%) à $12460 \$(0 \%)$ sur 40 ans. Ces exemples illustrent l'utilité de l'approche sur la base des bénéfices comme outil d'aide à la décision pour la conception et la gestion.

Resumen. La valoración basada en los beneficios de los árboles da alternativas para estimar con justeza el valor de los árboles, mientras que ilustra la contribución relativa de los diferentes tipos de beneficios. Este estudio comparado estima el valor de los árboles, obtenido usando aproximaciones costo-beneficio. La aproximación basada en costo usó el método de la fórmula del tronco del Council of Landscape and Tree Appraisers y la aproximación basada en el beneficio calculó el valor neto presente (NPV, total de beneficios futuros menos los costos descontados al presente) de los beneficios futuros y los costos, usando datos de crecimiento del árbol y modelos numéricos. En un ejemplo hipotético, el valor de un fresno de 40 años (Fraxinus pennsylvanica) fue \$5,807 (US) usando la aproximación basada en costo, y bien sea $\$ 3,012$ (para un árbol de Fort Collins, CO) o \$5,022 (para un árbol de Boulder, CO), usando la aproximación basada en beneficio. Este ejemplo, sin embargo, no consideró los costos de plantación y mantenimiento. En un ejemplo multi-árbol, de cinco pistaches (Pistacia chinensis), 15 años después de la plantación en las calles de Davis, CA, con la fórmula del tronco (basada en costo) el valor fue $\$ 8,756$, mientras que el valor basado en beneficio NPV fue negativa al descontar las tasas de 0-10\%. Los NPVs negativos ocurrieron debido a que los costos futuros de reparación de la acera fueron proyectados, una relación no completamente capturada en la evaluación basada en costo. La remoción y reemplazo de los cinco pistaches, primariamente, no fue efectiva en costo en $7 \%$ y $10 \%$ de tasas de descuento, debido a los altos costos de reparación de las aceras asociados con la permanencia de los árboles. La plantación de los cinco pistaches en su localización actual no fue una decisión económicamente sensible, pero la plantación de los mismos árboles en lugares cercanos hubiese ahorrado un estimado de $\$ 1,102(10 \%)$ a $\$ 12,460(0 \%)$ en 40 años. Estos ejemplos ilustran la utilidad de las aproximaciones basadas en beneficios como una herramienta de soporte en la toma de decisiones para diseño y mantenimiento.

Zusammenfassung. Die auf Vorteilen basierende Baumbewertung liefert alternative Schätzungen der bedeutsamen Baumwerte, während sie die relativen Beiträge der unterschiedlichen Bewertungen illustriert. Diese Studie vergleicht Baumwertschätzungen, die auf Kosten oder Vorteilen beruhen. Die Kostenbasierende Methode verwendet die Stamm-Formel-Methode vom Landschaftsplanungsamt und kalkuliert den gegenwärtigen Nettowert ( NPV: totale zukünftige Vorteile minus der gegenwärtigen Kosten) künftiger Vorteile und Kosten unter Einbezug der Wachstumsdaten und numerischer Modelle. In einem hypothetischen Beispiel beträgt der Wert einer 40 Jahre alten Grünen Esche (Frax. penn.) \$ 5.807 unter Anwendung der Kostenmethode oder \$ 3.102 (für einen Baum in Fort Collins, CO) oder \$ 5.022 (für einen Baum in Boulder, CO) unter Anwendung der Vorteilsbewertung. Dieses Beispiel berücksichtigte aber nicht die Pflanz- und Managementkosten. In einem Beispiel mit vielen Bäumen betrug der Kostenbasierende Wert einer 15 Jahre alten Pistazie (Straßenbaum in Davis, CA) \$ 8.756, während der Vorteilsbasierende Wert (NPV) negativ war und im Bereich zwischen $0-10 \%$ variierte. Negative NPVs tauchten auf, weil zukünftige Kosten für die Gehwegreparatur als Vorteil überwiegend betrachtet wurden. Dies stellt eine nicht voll erfasste Beziehung in der Kostenbasierenden Bewertung dar. Eine Entfernung und Ersetzung der 5 Pistazienbäume war nicht kosteneffektiv bei einer Rate von 7 und $10 \%$, hauptsächlich weil die hohen Reparaturkosten der Gehwege in Verbindung mit der Erhaltung der Bäume stark abgewertet wurden. Eine Pflanzung der 5 Pistazien an ihrem gegenwärtigen Standort war keine ökonomisch sinnvolle Entscheidung, aber eine Pflanzung derselben Bäume in ein nahebei gelegenes offenes Terrain hätte schätzungsweise $\$ 1.102(10 \%)$ bis $\$$ $12.460(0 \%)$ über 40 Jahre eingespart. Diese Beispiele illustrieren die Nützlichkeit des Vorteilsbasierenden Ansatzes als ein unterstützendes Mittel für Entscheidungen in der Gestaltung und Baummanagement. 